\title{
Effects of chitosan and emamectin benzoate on the reproductive system of Eobania vermiculata (Muller) land snails
}

\author{
M. A. Kandil ${ }^{1}$, E. A. Eweis ${ }^{1}$, A. Mobarak Soha ${ }^{2}$ and M. T. Nada Abbas ${ }^{2^{*}}$
}

\begin{abstract}
The reproductive system of snails represents essential organ that affects snail population size. Therefore, the present research was directed to evaluate the effect of two biopesticides chitosan (Ch) and emamectin benzoate (EMB) $\mathrm{LC}_{50}$ on the reproductive system of Eobania vermiculata (Muller). Land snails were treated using thin-film layer technique. Snails were dissected and organs of reproductive system were weighted and examined for any pathological changes at 24, 48 and $72 \mathrm{~h}$ post treatment. Moreover, steroidal hormones were determined after $72 \mathrm{~h}$ of treatment with either chitosan or emamectin benzoate in comparison to untreated snails. Results revealed that the penis and dart sac increased in size, while ovotestis was decreased at the 3 different periods than the same organs of untreated snails. In addition, there was swelling in the size of some organs, i.e penis and vagina. While there was stunting in the albumen gland at $72 \mathrm{~h}$ of treatment with Ch or EMB. However, histological examination showed damage of the ovotestis and atrophy of induced cells in the dart sac and penis. The incidents of both compounds on the level of steroidal hormones gave fluctuating results, either increasingly or decreasingly. In conclusion, data emphasize that both tested compounds caused reduction in the numerical density of the $E$. vermiculata reproductive system and consequently decreased their fertility, as well as reduction in its population.
\end{abstract}

Keywords: Eobania vermiculata, Reproduction system, Chitosan, Emamectin benzoate, Steroidal hormones

\section{Background}

Terrestrial gastropods form the most important threats of sustainable agriculture in many parts of the world (Barker, 2002). Moreover, they play an important role in transmitting and spreading diseases to cultivated plants (Godan, 1983). However, growers and farmers have often experienced difficulty in controlling land gastropods with conventional molluscicides and need to use non-conventional methods (Schuder et al., 2003). Land snail, Eobania vermiculata (Muller), is the most widespread snail species in the agricultural field and orchards in Egypt (El-Sayed, 2013). Avermectins, a group of 16membered macrocyclic lactones, are fermentation

\footnotetext{
* Correspondence: drnadataha2019@yahoo.com

${ }^{2}$ Harmful Animals Department, Plant Protection Research Institute, ARC, Nasr City, Cairo, Egypt

Full list of author information is available at the end of the article
}

products from Streptomyces avermitilis, a naturally occurring soil actinomycete. (Pitterna et al., 2009). Emamectin benzoate (EMB) is a novel macrocyclic lactone insecticide derived from the avermectin family with the substitution of an epi-methyl amino (-NHCH3) group for a hydroxyl $(-\mathrm{OH})$ group at the 4 -position on the disaccharide and is produced as benzoate salt insecticide. Chitosan $(\mathrm{Ch})$ is derived by deacetylation of chitin, the second most abundant natural biopolymer, which is the major component of protective cuticles of various crustaceans like crabs, shrimps, prawns, lobsters and cell walls of some fungi such as Aspergillus and Mucor (Kubota and Equchi, 1997). $\mathrm{Ch}$ is cheap, biodegradable and nontoxic to mammals. $\mathrm{Ch}$ as an inhibitor of chitin synthesis by inhibition of cholesterol building and inhibitor of oocyte wall formation or egg formation of nematodes (Wang et al., 2005). Both

\section{Springer Open}

(- The Author(s). 2020 Open Access This article is licensed under a Creative Commons Attribution 4.0 International License, which permits use, sharing, adaptation, distribution and reproduction in any medium or format, as long as you give appropriate credit to the original author(s) and the source, provide a link to the Creative Commons licence, and indicate if changes were made. The images or other third party material in this article are included in the article's Creative Commons licence, unless indicated otherwise in a credit line to the material. If material is not included in the article's Creative Commons licence and your intended use is not permitted by statutory regulation or exceeds the permitted use, you will need to obtain permission directly from the copyright holder. To view a copy of this licence, visit http://creativecommons.org/licenses/by/4.0/. 
compounds are nontraditional control agents and could be used to combat land snails.

Therefore, the main objective of this study was to evaluate the effect of both compounds (Ch and EMB) on the sexual hormonal disruption in $E$. vermiculata as well as examine their anatomical, histopathological impact on the reproductive system (hermaphrodite) and egg production.

\section{Materials and methods Tested pesticides}

(a) Emamectin benzoate Common name: Emamectin benzoate Molecular formula: $\mathrm{C}_{56} \mathrm{H}_{81} \mathrm{NO}_{15}\left(\mathrm{~B}_{1 \mathrm{a}}\right) ; \mathrm{C}_{55} \mathrm{H}_{79} \mathrm{NO}_{15}$ $\left(\mathrm{B}_{1 \mathrm{~b}}\right)$

Chemical name: (4' $R$ )-5-O-demethyl-4"' -deoxy-4'

'-(methylamino) avermectin $\mathrm{A}_{1 \mathrm{a}}+\left(4^{\prime \prime} R\right)-5-O-$ demethyl-25-de(1-methylpropyl)-4"' -deoxy-4' '-(methylamino)-25-(1-methylethyl) avermectin $\mathrm{A}_{1 a}$ (9:1); 4' '-deoxy-4' ' -(methylamino) avermectin B1 Source: Technical grade active ingredient was supplied by Syngenta company and formulated (Proact EC) were supplied by Agrochem 5\%

(b) Common name: Chitosan

Molecular formula: $\left(\mathrm{C}_{6} \mathrm{H}_{11} \mathrm{NO}_{4}\right)_{\mathrm{n}}$ Chemical name: (1,4)-2-Amino-2-desoxy-beta- $D$ glucan

Source: Technical grade active ingredient was supplied by Royal Company for Agricultural Development Chemical Compounds. Egypt (chitosole selanole EC) were supplied by Agrochem $50 \%$.

\section{Experimental snails}

Adults of the chocolate-band snail, Eobania vermiculata (Müller) were collected from untreated orchards of Ismailia Governorate, Egypt and transferred to the laboratory. Snails were placed in plastic boxes $(55 \times 65 \mathrm{~cm})$, covered with cloth netting and maintained under laboratory conditions of $27^{\circ} \mathrm{C}$ and $80 \% \mathrm{RH}$. Animals were daily fed on lettuce leaves and kept to be acclimatized for 2 weeks. Dead snails were immediately removed (Singh and Singh, 2000).

\section{Bioassay}

Serial concentrations of each compound were diluted by water. Two milliliters of water for each $\mathrm{Ch}$ concentration $(25,50,75,100,125$ and $150 \mathrm{ppm})$ and EMB concentration $(75,100,125,150,175$ and $200 \mathrm{ppm})$ was spread on the inner surface of a Petri-dish $(9 \mathrm{~cm}$ diameter), which was gently moved in circles. Water evaporated under room conditions in few minutes leaving a thin-layer film of each compound on the surface of the Petri dish. Land snails, E. vermiculata were exposed to $\mathrm{LC}_{50}$ of the 2 tested compounds chitosan (Ch) and emamectin (EMB) by using the thin-layer film, according to Asher and Mirian (1981). For $72 \mathrm{~h}$, mortality rate was recorded and corrected according to Abbotts' formula (1925). LC $\mathrm{C}_{50}$ values were estimated and the toxicity lines were drawn according to Finney (1971).

\section{Anatomical studies \\ The weight of the organs of reproductive system studies}

The snails of the treatment that survived were anesthetized by $1 \%$ solution of chloral hydrate for $12 \mathrm{~h}$. Organs of the genital system were removed and weighted. Observations of organ features for treated individuals compared to the untreated ones were described, using a binocular stereoscope, according to Vauflery and Kerhoas (2000) with slight modification.

\section{Histopathological studies}

The histopathological effects of $\mathrm{Ch}$ and EMB on the ovotestis, albumen gland, penis and dart sac of treated $E$. vermiculata were observed and described as compared to the same organ of untreated snails. The method was done according to Banchroft et al. (1996).

\section{Steroidal hormone determination}

Animals treated with $\mathrm{LC}_{50}$ of each compound were subjected to the determination of the level of some sex hormones, i.e. testosterone, progesterone and estrogen steroidal hormones. Determination was carried out at 3 intervals $(24,48$ and $72 \mathrm{~h}$ ). Hemolymph was collected from untreated and treated snails according to the method described by Dubhomcom (1998) with some modifications. The steroid hormones were quantitatively determined, using enzyme immunoassay ELISA Kit and micro titer ELISA reader (Expert plus V2.0, CB4OFJ, Biochrom Ltd, Cambridge, UK) at the Hormonal Unit Biochemistry Department, Animal Health Research Institute, Dokki, Giza. Testosterone $(\mathrm{T})$, progesterone $(\mathrm{P})$ and estrogen $(\mathrm{E})$ were determined, using enzyme immunoassay ELISA Kit (Immunospec Corportion, USA), Cat. No. B115, No. B113 and No. B111, respectively.

\section{Statistical analysis}

Data were analyzed using SPSS v 25.0 (SPSS for Windows, SPSS Inc., Chicago, IL). One-way analysis of variance (ANOVA) was applied, and Duncan test was used to compare means to know the most potent formula at the significant level of $p<0.05$ (SPSS, 2017). 


\section{Results and discussion}

Effects of tested biopesticides on Eobania vermiculata using the residual film technique

The molluscicidal activity of EMB and Ch against E. vermiculata was determined under laboratory conditions. $\mathrm{LC}_{50}$ value of $\mathrm{Ch}$ to $E$. vermiculata was lower than that of EMB (Table 1). The results showed that $\mathrm{Ch}$ exhibited 2-fold molluscicidal potency than EMB. Ch was more effective than EMB against E. vermiculata. The molluscicidal activity of $\mathrm{Ch}$ was higher than that of EMB and may be due to the mechanism of chitosan in reducing cholesterol. Previous studies mentioned that chitosan acted as a weak anion exchange resin and reduced cholesterol by causing a depletion in its absorption in the small intestine and enhanced bile acid excretion (Liu et al., 2008). This was in agreement with He et al. (2008) who showed that in obese albino male rats, chitosan had an impact on fertility. In addition, it was revealed that chitosan could put off the atherogenic process, associated with hyperlipidemia, by reducing blood cholesterol level. Chitosan increased testicular weight and decreased the lipid content due to the ability of interacting with the cell membrane. However, the mechanism of action of EMB associated with the effect on the $\delta$-aminobutyric acid (GABA) receptors and open chloride channels of animal cells result to hyperpolarization (Maioli et al., 2013). Moreover, Ma and Li (2011) suggested that Abamectin had a lethal toxic action on the freshwater snails, Physa acuta.

\section{Influence on the weight of the organs of the reproductive system}

Data in Table 2 showed that the weight of the reproductive organs of snails treated with $\mathrm{LC}_{50}$ of $\mathrm{Ch}$ and $\mathrm{EMB}$ using thin-layer film technique compared to untreated snails. The ovotestis was highly sensitive recording a high decrease in post treatment weight. The weight of ovotestis was decreased to 6.3, 50.8 and $96.3 \%$ after 24, 48 and $72 \mathrm{~h}$, respectively, when treated with $\mathrm{Ch}$. For snails treated with EMB, their ovotestis organ was decreased to $76.8,40.7$ and $0.05 \%$ after 3 tested periods, respectively. The same trend occurred with the albumen gland, whereas it decreased to 60.2, 96.4 and $65.3 \%$ in the case of Ch treatment and decreased to 60.8, 30.6 and $25 \%$ in the case of EMB after 24, 48 and $72 \mathrm{~h}$, respectively. Besides, the dart sac and penis weights were

Table $\mathbf{1} \mathrm{LC}_{50}$ values of chitosan and emamectin benzoate against Eobania vermiculata using thin film technique

\begin{tabular}{|c|c|c|c|c|}
\hline \multirow[t]{2}{*}{ Compounds } & \multirow{2}{*}{$\begin{array}{l}\mathrm{LC}_{50} \\
(\mathrm{ppm})\end{array}$} & \multicolumn{2}{|c|}{ Confidence limits 95\% } & \multirow[t]{2}{*}{ Slope \pm SE } \\
\hline & & Lower & Upper & \\
\hline Chitosan & 68.8 & 62.943 & 74.987 & $2.3677 \pm 0.3099$ \\
\hline Emamectin benzoate & 120.127 & 101.34 & 138.599 & $6.3459 \pm 0.4633$ \\
\hline
\end{tabular}

increased after treatments with both the tested compounds. They were increased to 39.7, 644.0 and $975.2 \%$ and $260.2,522.3$ and $731.4 \%$ in case of the Ch and EMB treatments, respectively, after 3 tested periods. From the previous results, the decrease in weight of ovotestis or hermaphrodite gland may be due to the inhibition of some processes and deformities within these organs. Also, the increasing size in the dart sac and penis may be reflected to an inflammatory reaction. Obtained results are in agreement with Wijdenes et al. (1983) who stated that the function of the hermaphrodite gland which acts as a reservoir for sperm and ovaries and responsible for egg formation. Also, it was possible that the endocrine stimulation of the gonad was affected (Berset de Vaufleury et al., 1986). In addition, the anatomic alterations showed the absence of secretion of polysaccharide by albumen gland, galactogen being the main component of the albumen gland during the phase of reproduction (Nieland and Goudsmid 1969).

The same type of regulation also existed for the oviduct, the ovotestis diminished in weight after exposure to pesticides (Bride and Gomot 1988). This information showed how the study of various aspects of reproduction (mating, laying and weight of the reproductive organs) can bring complementary elements of information on the modes of action of candidate compounds (Russell et al., 1981). However, Watanabe et al. (1985) revealed that M. edulis exposed to molinate, thiobencarb, (chloronitrofen) CNP and chromethoxinyl, under laboratory conditions accumulated the pesticide residues at high levels in the gonad and midgut gland, which was much higher in lipid content than those in the gill and other organs. Gunkel and Streit (1980) indicated that atrazine was rapidly accumulated in the liver, brain, gill, intestine and gallbladder of the bivalve Coregonus fera, in laboratory experiments, and investigated that high accumulation rates occur in organs of bivalve that have a highly blood circulation (e.g., liver, brain, gill, intestine). Since the blood circulation of the fresh water snails is an open blood vascular system. Reinecke et al. (1999) found that the prolonged contamination (7 to 10 weeks) at low levels (200 and $400 \mu \mathrm{g} \mathrm{Cd} \mathrm{g}$ food) completely inhibited the development of the hermaphrodite gland and prevented the formation or laying of eggs. It is possible to use the development of the genital tract and mainly of the hermaphrodite gland, as the marker of endocrine disturbances. As bioindicators of Cd toxicity, snails are the most sensitive (total inhibition of reproduction at concentrations of 200 and $400 \mu \mathrm{g} \mathrm{g}^{-1}$ ).

\section{Pathological changes of the reproductive system}

The basic structure of the reproductive system of snails was described by Siddiqi and Aurangzeb (1984). It consists of hermaphrodite or ovotestis, into the genital 
Table 2 Mean weights $L C_{50}$ of chitosan or emamectin benzoate of the reproductive system organs of Eobania vermiculata using the residual film technique

\begin{tabular}{|c|c|c|c|c|c|}
\hline \multirow[t]{3}{*}{ Group } & \multirow{3}{*}{$\begin{array}{l}\text { Tested } \\
\text { periods (h) }\end{array}$} & \multicolumn{4}{|c|}{ Mean weight genital tract organs (fresh tissues in g) } \\
\hline & & Ovotestis & Albumen gland & Dart sac & Penis \\
\hline & & Mean \pm SD & Mean \pm SD & Mean \pm SD & Mean \pm SD \\
\hline Control & 0 & $0.0377 \pm 0.00497$ & $0.2657 \pm 0.0591$ & $0.0109 \pm 0.00370$ & $0.0155 \pm 0.00304$ \\
\hline \multirow[t]{3}{*}{ Chitosan } & 24 & $0.0240 \pm 0.00707$ & $0.1599 \pm 0.107$ & $0.0433 \pm 0.0078$ & $0.0428 \pm 0.0215$ \\
\hline & 48 & $0.0191 \pm 0.0095$ & $0.0256 \pm 0.0162$ & $0.0702 \pm 0.0072$ & $0.0598 \pm 0.0270$ \\
\hline & 72 & $0.0036 \pm 0.00105$ & $0.0173 \pm 0.0709$ & $0.106 \pm 0.0423$ & $0.1484 \pm 0.0869$ \\
\hline \multirow[t]{3}{*}{ Emamectin } & 24 & $0.0289 \pm 0.00967$ & $0.161 \pm 0.0650$ & $0.0283 \pm 0.0083$ & $0.0951 \pm 0.0065$ \\
\hline & 48 & $0.0153 \pm 0.00361$ & $0.0815 \pm 0.0157$ & $0.0569 \pm 0.0238$ & $0.1128 \pm 0.0125$ \\
\hline & 72 & $0.00203 \pm 0.000709$ & $0.0645 \pm 0.0199$ & $0.0797 \pm 0.0141$ & $0.204 \pm 0.073$ \\
\hline$p$ value & & 0.000 & 0.001 & 0.001 & 0.002 \\
\hline$F$ value & & 9.867 & 5.368 & 12.512 & 11.878 \\
\hline
\end{tabular}

The mean of each organ from the genital organs showed a significant difference than in control in all the treatments of the two bioagent control $(p$ value $<0.05$ )

atrium comes the penis, then the vagina and pass down to the common hermaphrodite duct then the albumen gland. The teratogenic effect of $\mathrm{Ch}$ on the reproductive system of E. vermiculata was shown in Fig. 1. Observed is the swelling incidence in the size of genital organs compared to that of the control. Also, a severe swelling in the sizes of the penis, vagina, dart sac; besides, stunting in the albumen gland and tumor in the free oviduct were shown but the sperm oviduct appeared normal. The malformation effect of EMB on the reproductive system of E. vermiculata was elucidated in Fig. 2 . It can be seen as mild swelling in the penis, vagina and dart sac, in addition to stunting and rupture in the albumen gland. On the contrary, free oviduct and sperm oviduct were unaffected. Moreover, several pathological impacts of $\mathrm{Ch}$ on treated snails were observed such as swelling in the acini of ovotestis and eggs' disappearance. In the case of the EMB treatment, a rupture and swelling in the acini of ovotestis were observed. This action may be caused by the reduction in the level of protein in the ovotestis or to stunting in the albumen gland as it is responsible for egg formation. Mobarak (2016) studied the effect of chlorfluazuron on the reproductive system of snails compared to the untreated animals. The compound caused severe swelling of the penis, vagina, sperm oviduct, and albumen gland, and in the ovotestis but the eggs were absent. Srivastava and Singh (2015) also found that the $\mathrm{LC}_{50}$ of clove plant extract (Syzygium aromaticum) on the fresh water snail Lymnaea acuminate caused significant reduction in free amino acid, protein, DNA and RNA in the ovotestis of snail, L. acuminate after $24 \mathrm{~h}$ post treatment..

\section{Histopathological effect}

The histopathological findings of the genital organs of treated E. vermiculata with $\mathrm{LC}_{50}$ of $\mathrm{Ch}$ or $\mathrm{EMB}$ as

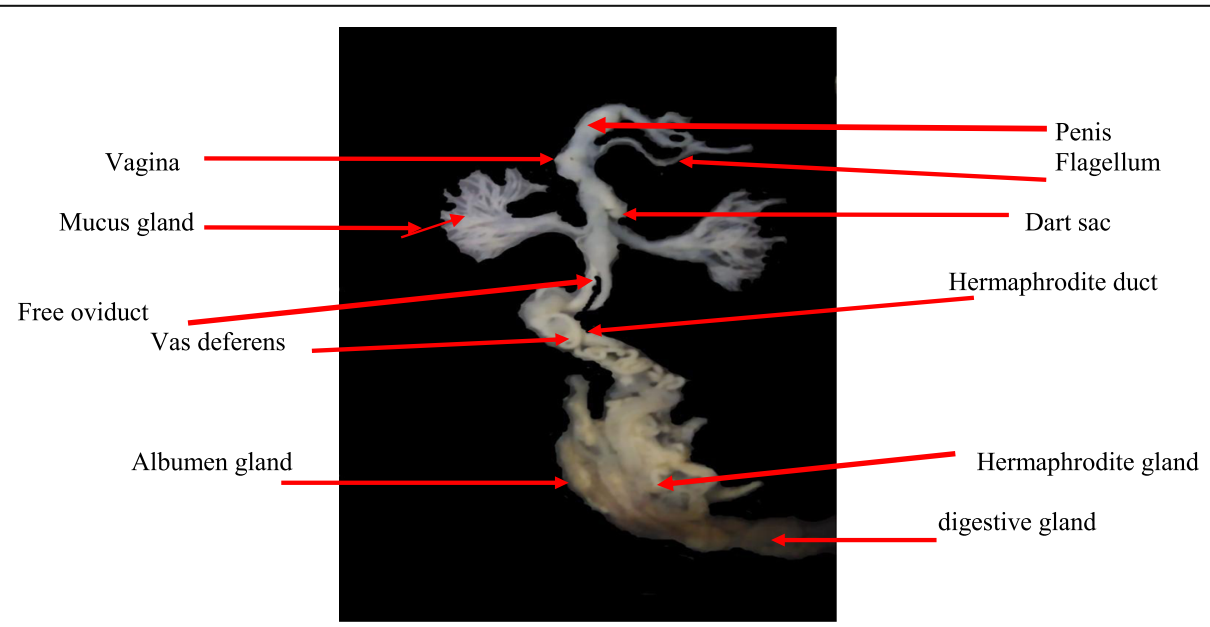

Fig. 1 Reproductive system of land snail, Eobania vermiculata treated with chitosan. 


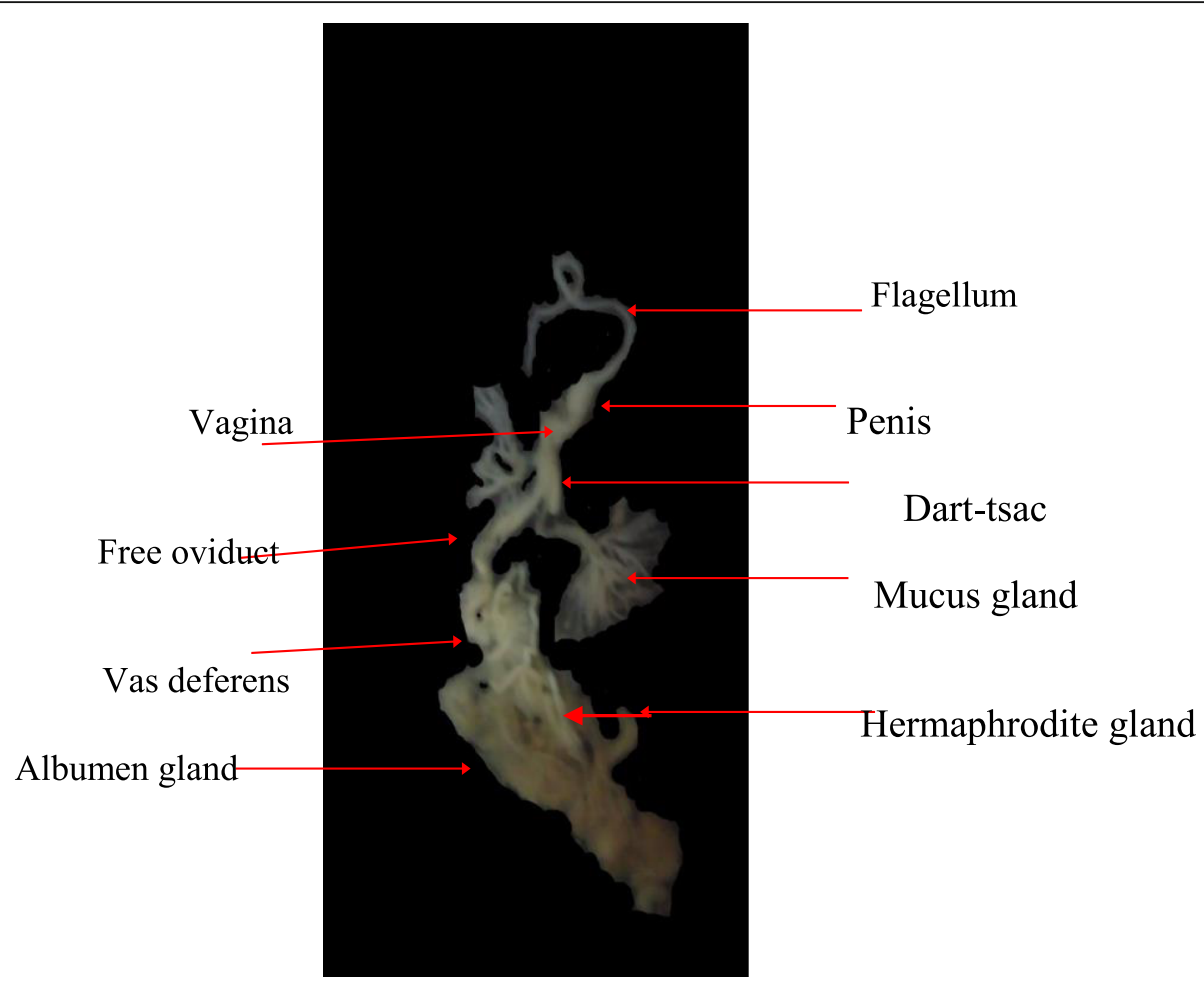

Fig. 2 Reproductive system of land snail, Eobania vermiculata treated with Emamectin benzoate

compared to untreated ones are shown in Figs. 3, 4 and 5. In the case of the ovotestis, normal histological structure of the ovarian of untreated snails was shown in Fig. 3. In the treated snails with $\mathrm{Ch}$, necrobiotic change was detected in the ova and some follicles as shown in Fig. 4. Concerning EMB, it was noticed that there was no histopathological alteration in the ovarian structure in Fig. 5. Histopathological examination of the sperm sac showed that treatment with $\mathrm{Ch}$ or EMB caused reduction in the spermatozoa concentration in the degenerated sac compared to the untreated snails. In the other side, the histopathological changes in the albumen gland of treated animals with $\mathrm{Ch}$ were induced vacuolar degeneration, necrosis and diffuse manner all over the cellular component. EMB treatments caused vacuolar degeneration with nuclear pyknosis in the cellular component. Otherwise,

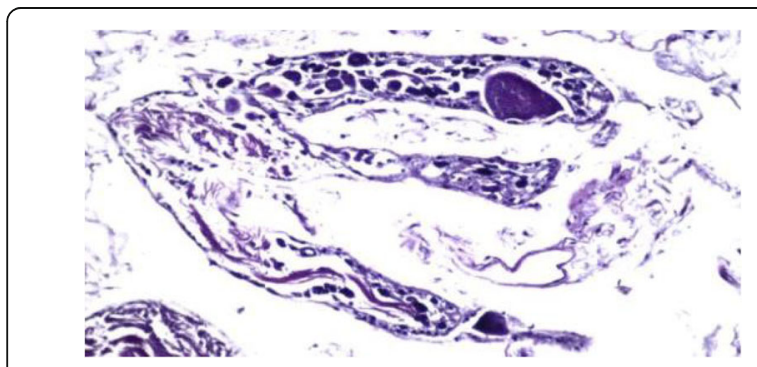

Fig. 3 Ovotestis of Eobania vermiculata gp untreated snail (I-1) histopathological effect of the penis showed desquamation in the lining of degenerated epithelium cells in focal manner at Ch treatments; however, EMB caused atrophy in the surrounding stroma, while the lining of the epithelium showed necrosis and desquamation. The histopathological studies in the lining of the epithelium of snails' dart sac showed vacuolization and hypertrophy by $\mathrm{Ch}$ treatment, but EMB caused hypertrophy and hyperplasia compared to the untreated snails. These results are in agreement with Zhou et al. (1993) who recorded that the decrease in the number of spermatozoa along with their degeneration and also reduction in acini numbers for the snail, Biomphalaria glabrata treated with niclosamide and

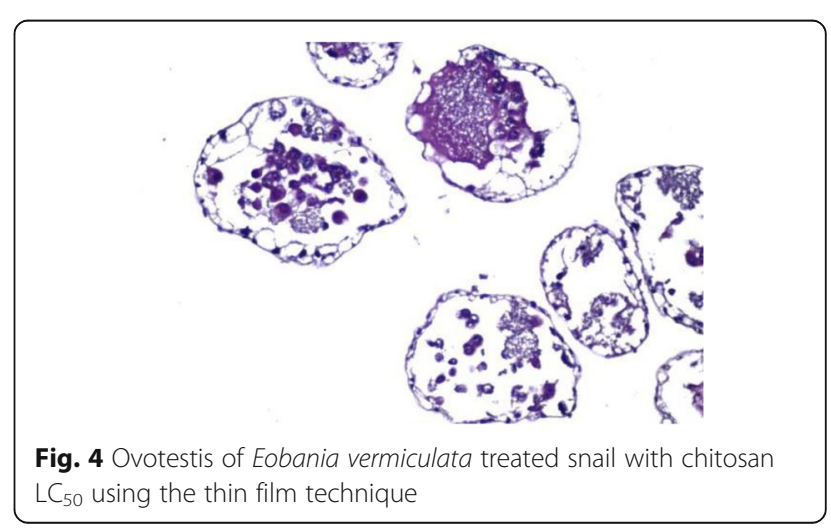




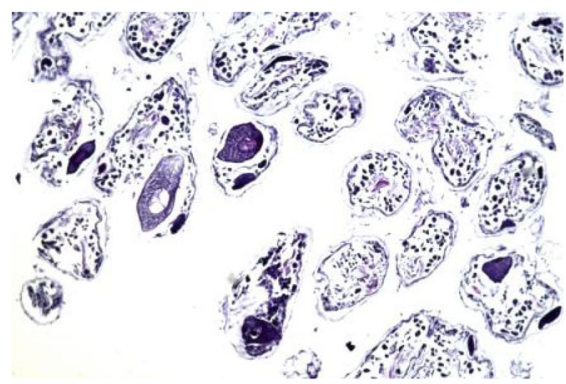

Fig. 5 Ovotestis of Eobania vermiculata treated with emamectin benzoate $L C_{50}$ using the thin film technique

extracts of Eucalyptus camaldulensis. The results are also in accordance with those obtained by Amaeze et al. (2011) who observed necrosis in the tissues of genital organs of the land snail, Archachatina marginata when exposed to a high dose of NPK balanced fertilizers. Parvate and Thayil (2017) stated that the snails exposed to $20 \%$ of $\mathrm{LD}_{50}$ from clove oil after 24 $h$ showed mild degenerative changes in the sperms along with a reduction in sperm density within the acini of ovotestis, while severe degeneration of sperms was observed in snails treated with $60 \%$ of the $\mathrm{LD}_{50}$ after $24 \mathrm{~h}$ along with necrosis of sertoli cells at intercellular level.

\section{Effect of the tested compounds on steroidal level hormones}

Data in Table 3 showed the level of steroidal hormones in the hemolymph of the land snail, $E$. vermiculata after

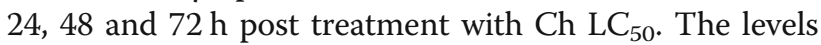
of testosterone, progesterone and estradiol hormones were reduced to 75,72 and $80 \%$ than those of the untreated snails, after $24 \mathrm{~h}$ of treatment, respectively.
However, a significant increase to 120, 250 and $160 \%$ occurred after $48 \mathrm{~h}$, respectively. Fluctuated data were recorded after $72 \mathrm{~h}$, in which testosterone and progesterone levels were decreased to 112 and $150 \%$, respectively compared to the control. In contrast, estradiol hormone increased to $200 \%$. In the case of EMB, significant increase was recorded for the levels of testosterone, progesterone and estradiol hormones after $24 \mathrm{~h}$. The same result occurred after 48 and $72 \mathrm{~h}$; it gave 150, 216 and 240\%, and 100, 134.8 and 200\%, respectively. Finally, Ch and EMB caused a hormonal disruption as they interfere with the endocrine biosynthetic pathway causing non forming eggs in the ovotestis. The fluctuation in the steroidal level hormones increased or decreased due to the harmful effect of the 2 compounds on the site, which produced these hormones. Consequently, the reproduction and egg laying were affected. The endocrine systems of invertebrates generally regulate the same processes that are found in vertebrates such as development, growth and reproduction (Oehlmann and Schulte-Oehlmann 2003). The results agree with Oehlmann et al. (1996) who recorded an increase in the testosterone concentrations in Mucella labillus after exposure to organic compounds. The biocide tributyltin exposure induced imposex and elevated immuno-detectable testosterone levels in the mud snail (Bettin et al. 1996). Therefore, it is likely that previous reports of increased testosterone levels with TBT exposure actually reflected the increases in ratio of free levels to esterify the testosterone (Addo et al. 1989). These observations were consistent with the hypothesis that TBT interferes with the storage of testosterone as fatty acid esters (Mensink et al., 2002). The fatty acid esterification of testosterone increased the lipophilicity of the testosterone molecule and presumably facilitated its storage in lipoidal matrices, while reducing its bioactivity, bioavailability and

Table 3 Effect of $L C_{50}$ of chitosan and emamectin on the level of sex steroidal hormones of Eobania vermiculata using a thin-layer film technique

\begin{tabular}{|c|c|c|c|c|}
\hline \multirow[t]{2}{*}{ Group } & \multirow[t]{2}{*}{$\begin{array}{l}\text { Duration } \\
\text { (h) }\end{array}$} & \multirow{2}{*}{$\begin{array}{l}\text { Estradiol } \\
(\mathrm{pg} / \mathrm{ml}) \\
\text { Mean } \pm \text { SD }\end{array}$} & \multirow{2}{*}{$\begin{array}{l}\text { Progesterone } \\
(\mathrm{ng} / \mathrm{ml}) \\
\text { Mean } \pm \mathrm{SD}\end{array}$} & \multirow{2}{*}{$\begin{array}{l}\text { Testosterone }(\mathrm{ng} / \mathrm{ml}) \\
\text { Mean } \pm \mathrm{SD}\end{array}$} \\
\hline & & & & \\
\hline Control & 0 & $5.0000 \pm 0.21000$ & $0.2500 \pm 0.04000$ & $0.04000 \pm 0.001000$ \\
\hline \multirow[t]{3}{*}{ Chitosan } & 24 & $4.0000 \pm 0.13000$ & $0.1800 \pm 0.03000$ & $0.002000 \pm 0.03000$ \\
\hline & 48 & $8.0000 \pm 0.044000$ & $0.3000 \pm 0.07000$ & $0.10000 \pm 0.010000$ \\
\hline & 72 & $10.0000 \pm 0.56000$ & $0.2800 \pm 0.05000$ & $0.06000 \pm 0.004000$ \\
\hline \multirow[t]{3}{*}{ Emamectin } & 24 & $10.0000 \pm 0.34000$ & $0.4467 \pm 0.10116$ & $0.11000 \pm 0.010000$ \\
\hline & 48 & $12.0000 \pm 74000$ & $0.540 \pm 0.0600$ & $0.004000 \pm 0.06000$ \\
\hline & 72 & $10.0000 \pm 0.88000$ & $0.3367 \pm 0.04041$ & $0.04000 \pm 0.001000$ \\
\hline$p$ value & - & 0.000 & 0.000 & 0.000 \\
\hline$F$ value & & 90.238 & 12.415 & 84.454 \\
\hline
\end{tabular}

The mean of each hormone from the steroidal hormones showed a significant difference than that of the control in all the treatments of the two compounds during different intervals ( $p$ value $<0.05$ ) 
susceptibility to elimination processes (Borg et al. 1995). The results also agree with Ofem et al. (2014) who suggested that leaves' extract of Viscum album contain potent agents with potentials to increase serum testosterone concentrations. The increase in testosterone levels may be due to some potent agents in the extract that stimulated the synthesis and subsequent release of these hormones in the anterior pituitary gland and ovary or probably promoted the cholesterol catabolism.

El-Emam et al. (2017) found that exposure of Biomphlaria alexandrina to methanol extract of Cerea citrinus and Zingus officinale, while $17 \beta$-estradiol was elevated compared to the control group. The latter mechanism is based on complete or partial blocking of the specific receptor. Regarding the estrogen receptor, this mechanism was only applied when the endocrine disruptor concentration was high, because the affinity of endocrine disruptors for the estrogen receptor was usually many times lower than that of 17-beta-estradiol (Schettler et al. 2003).

\section{Conclusion}

The results illustrated that the 2 tested bio-compounds, $\mathrm{Ch}$ and EMB exhibited changes in the weight of reproductive organs of the land snail, E. vermiculata. Both compounds induced malformation in the reproductive system and accompanied with fluctuation in the levels of endocrine hormones (either increased or decreased) by preventing the egg production in snails. Therefore, this effect should alter the population number of snails in the crops to a level less than the economic injury level.

\section{Abbreviations}

Ch: Chitosan; EMB: Emamectin benzoate $(E M B)$; $E$ : Estrogen; $L_{50}$ : Median lethal concentration; P: Progesterone; T: Testosterone

\section{Acknowledgements}

NM T wishes to thank the head of the Department of Pesticides and Entomology, Faculty of Agriculture, University of Cairo for providing laboratory facilities. And thanks for the technical help by Ashraf El-kadi.

\footnotetext{
Authors' contributions

NMT analyzed and interpreted the hemolymph data of the land snails regarding the efficacy of the two bioagents control on the sexual hormones. NMT made the histological examination sections of the reproductive system , and was a major contributor in writing the manuscript. All authors read and approved the final manuscript.
}

\section{Funding}

This work was financially supported by the Faculty of Agriculture, University of Cairo.

\section{Availability of data and materials}

The datasets generated and analyzed during the current study are available.

Ethics approval and consent to participate

Not applicable.

\section{Consent for publication}

This study does not contain any individual person's data.

\section{Competing interests}

The authors declare that they have no competing interests in the text.

\section{Author details}

${ }^{1}$ Economic Entomology and Pesticides Department, Faculty of Agriculture, Cairo University, Giza, Egypt. ${ }^{2}$ Harmful Animals Department, Plant Protection Research Institute, ARC, Nasr City, Cairo, Egypt.

Received: 31 October 2019 Accepted: 20 February 2020

Published online: 02 March 2020

\section{References}

Abbott WS (1925) A method of computing the effectiveness of an insecticide. J. Econ. Entomol 18:265-267

Addo SB, Diamond E, Hollander VP(1989) Non-polar extracts of serum from males contain covert radioimmunoassayable testosterone Steroids 54:257269.

Amaeze NH, Ugwoeje D, Engonwamn Rl (2011) Histopathological and physiological effects of selected agrochemical on non target Arachtina margrinata. Yectivenscys 1(2):21-26

Asher RS, Mirian F (1981) The residual contact toxicity of Bay Sir 8514 to Spodoptera littoralis larva. Phytoparasitica 9(2):133-137

Banchroft JD, Stevens A, Turner DR (1996) Theory and practice of histological techniques, 4th edn. Churchill Livingstone, New York, London, San Francisco, Tokyo

Barker GM (2002) The biology of terrestrial mollusks. Landcare Research, Hamilton, New Zealand, p 147

Berset de Vaufleury JP, Bride GL (1986) Mise en évidence du rôle endocrine de la gonade dans le développement de l'appareil genital de l'e scargot Helix aspersa. C R Soc Biol Fr 180:190-196

Bettin C, Oehlmann J, Stroben E (1996) TBT-induced imposex in marine neogastropods is mediated by an increasing androgen level. Helgol Meeresunter 50:299-317

BorgW SC, Pahuja SL, Hochburg RB (1995) Long-lived testosterone esters in the rat. Proc Natl Acad Sci USA 92:1545-1549

Bride J, Gomot L (1988) La synthèse polysaccharidique in vitro de l'oviducte 440 d'Helix aspersa: un bioessai pour éprouver l'activité d'organes endocrines, la gonade et le complexe neuro endocrine céphalique. C R Acad Sci Paris. 307: 199-204

Dubhomcom HMK (1998) Studies on some land snails of agriculture and medicinal importance in a local environment. M.Sc. Thesis Zoology Department. Fac of Agric Ain Shams Univ. , 214pp.

El-Emam MA, Osman GY, Abdel-Hamid H, Mohamed AH, Ali RE (2017) Determination of egg laying capacity, sex hormones and mortality of Biomphalaria alexandrina snails exposed to methanol extract from curcumin and the plants Callistemon citrinus and Zingiber officinale. J. Biosci. Appl. Res 3:97-109

El-Sayed HE (2013) Survey and distribution of terrestrial snails in fruit orchards and ornamental plants at Alexandria and El-Beheira Governorates, Egypt, Alex. Sci. Exch. J 34(2):242-248

Finney DJ (1971) Probit analysis.3rd Ed. Cambridge Univ. Press, London

Godan D (1983) Pest slugs and snails. Biology and Control. Springer Verlag, Berlin Heidelberg New York, p 89

Gunkel G, Streit B (1980) Mechanisms of bioaccumulation of a herbicide (atrazine s-triazine) in a freshwater mollusk (Ancylus fluviatilis Mull) and a fish (Coregonus fera Jurine). Water Res 14:1573-1584

He W, Guo X, Zhang M (2008) Transdermal permeation enhancement of Ntrimethyl chitosan for testosterone. Int J Pharm 356(1-2):82-87

Kubota N, Equchi Y (1997) Facile preparation of water-soluble N-acetylated chitosan and molecular weight dependence of its water-solubility. Polymer Journal 29:123-127

Liu J, Zhang J, Xia W (2008) Hypocholesterolemic effects of different chitosan samples in vitro and in vivo. FoodChem. 107:419-425

Ma JG, Li XY (2011) Acute toxicity of lambda cyhalothrin, imidaclopid and avermectin on Physa acuta. J. Hydroecol. 32:100-104

Maioli MA, de Medeiros HCD, Guelfi M, Trinca V, FTV P, Mingatto FE (2013) The role of mitochondria and biotransformation in abamectin-induced cytotoxicity in isolated rat hypatocytes. Toxicol.in Vitro 27:570-579

Mensink BP, Kralt H, Vethaak AD, Hallers-Tjabbes C, Koeman JH, Hattum BV (2002) Imposex induction in laboratory reared juvenile Buccinum undatum by tributyltin (TBT). Environ Toxicol Pharmacol C 11:49-65 
Mobarak SA (2016) The malformation effect of caprice (chlorfluazuron) compound on the reproductive system of land snail Eobania vermiculata. $J$ Basic Appl Zool 74:51-55

Nieland ML, Goudsmit EM (1969) Ultrastructure of galactogen in the albumen 441 gland of Helix pomatia. J Ultrastruct Res 29:119-140

Oehlmann J, Fioroni P. Stroben E, Markert B (1996) Tributyltin (TBT) effects on Ocinebrina aciculate (Gastropoda: Muricidae) imposex development, sterilization, sex change and population decline. Sci.Total Environ 188:205223

Oehlmann J, Schulte-Oehlmann U (2003) Endocrine disruption in invertebrates. Pure Appl Chem 75:2207-2218

Ofem OE, Anatai AB, Essier NM, Oka VO (2014) Enhancement of some sex hormone concentration by consumption of leaves extract of Viscum album in rats. Asian J Med Sci 5(3):87-90

Parvate YA, Thayil L (2017) Toxic effect of clove oil on the survival and histology of various tissues of pesti ferrous land snail Achatina fulica. J Exp Biol Agric Sci 5(4):492-505

Pitterna T, Cassayre J, Hüter OF, Jung PMJ, Maienfisch P, Kessabi FM, Cary I (2009) New ventures in the chemistry of avermectins. Bioorg Med Chem 17:40854095

Reinecke SA, Prinsloo MW, Reinecke AJ (1999) Resistance of Eisenia fetida (Oligochaeta) to cadmium after long-term exposure. Ecotoxicol Environ. Saf 42:75-80

Russell LK, De Haven Jl, Botts RP (1981) Toxic effects of cadmium on the garden snail (Helix aspersa). Bull Environ Contam Toxicol 26:634-640

Schettler T, Solomon G, Kaplan J, Valenti M (2003) Generations at risk: how environmental toxicants may affect reproductive health in California. George Lithograph, Brisbane, CA, USA

Schuder I, Porta G, Bennisonb J (2003) Barriers, repellents and antifeedants for slug and snail control. Crop Protection:1033-1038

Siddiqi MN, Aurangzeb T (1984) General anatomy and reproductive system of the land snail (Bensoniesj acquementi). Pakistan J. Agric. Res. 5(2):118-123

Singh A, Singh DK (2000) Molluscicidal activity of Annona squamosa alone and in combination with other plant derived molluscicides. J. Herb Med Plants 8: 23-29

SPSS (2017) IBM SPSS Statistics for Windows (Version 25.0). IBM Corp, Armonk Chicago, IL.

Srivastava AK, Singh VK (2015) Action of bait containing Eugenol (Syzygium aromaticum) on biochemical changes in fresh water snail Lymnaea acuminate. Biochem. Mol. Biol. (BMB) 3(1):1-6

Vaufleury AG, Kerhoas I (2000) Effects of cadmium on the reproductive system of the land snail Helix aspersa. Bull., Environ., Contam.,Toxicol 64:434-442

Wang X, Fan DY, Liu H, Hu Y (2005) Chitosan metal complexes as antimicrobial agent: synthesis, characterization and structure-activity study. Polymer Bulletin 55:105-113

Watanabe S, Watanabe S, Ito K (1985) Accumulation and excretion of herbicides in various tissues of mussel. J Food Hyg Soc 26:496-499

Wijdenes J, Vincent C, Griffond B, Gomot L (1983) Ultra-structural evidence for the neuro-endocrine innervation of the dorsal bodies and their probable physiological endocrinology. North-Holland Publishing Company Amsterdam, pp 147-152

Zhou X, Upatham MES, Kruatrachue SMP (1993) Effects of niclosamide and Eucalyptus camaldulensis on Biomphalaria glabrata the snail intermediate host of Schistosoma mansoni. J Sci Soc Thailand 19:117-128

\section{Publisher's Note}

Springer Nature remains neutral with regard to jurisdictional claims in published maps and institutional affiliations.

\section{Submit your manuscript to a SpringerOpen ${ }^{\circ}$ journal and benefit from:}

- Convenient online submission

- Rigorous peer review

- Open access: articles freely available online

- High visibility within the field

- Retaining the copyright to your article

Submit your next manuscript at $\boldsymbol{\nabla}$ springeropen.com 